\title{
Increased magnitude of relaxation to oestrogen in aorta from oestrogen receptor $\beta$ knock-out mice
}

\author{
B-O Nilsson, E Ekblad, T Heine and J-Å Gustafsson ${ }^{1}$
}

Department of Physiological Sciences, Lund University, Sölvegatan 19, S-223 62 Lund, Sweden

1Department of Medical Nutrition, Karolinska Institute, Novum, S-141 86 Huddinge, Sweden

(Requests for offprints should be addressed to B-O Nilsson)

\begin{abstract}
Micromolar concentrations of the biologically active oestrogen $17 \beta$-oestradiol reduce agonist-induced force in vascular preparations through an unidentified mechanism. The aim of the present study was to investigate the importance of oestrogen receptor $\beta$ (ER $\beta)$ for oestrogen-induced vascular relaxation. $17 \beta$-oestradiol was added to aortic rings from ER $\beta$ knock-out (-/-) and wild-type (+/+) mice precontracted with noradrenaline. $17 \beta$-oestradiol caused a concentrationdependent $(1-100 \mu \mathrm{M})$ relaxation of aortic rings from both $-/-$ and $+/+$ animals of both sexes. Rings from male and female $-/-$ mice were more sensitive to $17 \beta$-oestradiol than those from
\end{abstract}

+/+ mice. Medial thickness, determined by computerized image analysis, was similar in rings from $-/-$ and $+/+$ animals. Endothelium, as determined by immuno-cytochemistry, was present in -/- and +/+ aorta. Maximal noradrenaline evoked force and sensitivity to noradrenaline were similar in both groups. In summary ER $\beta$ modulates vascular relaxation to $\mu \mathrm{M}$ concentrations of oestrogen; lack of ER $\beta$ renders the vascular wall supersensitive to $17 \beta$-oestradiol. Lack of ER $\beta$ caused no change in vascular wall morphology suggesting that this ER subtype is not involved in vascular structure development.

Journal of Endocrinology (2000) 166, R5-R9

\section{Introduction}

$17 \beta$-oestradiol causes, in $\mu \mathrm{M}$ concentrations, reversible relaxation of precontracted vascular preparations (Jiang et al. 1992, Kitazawa et al. 1997). Relaxation is mainly evoked by $17 \beta$-oestradiol while other oestrogens such as $17 \alpha$-oestradiol, oestriol or oestrone have a much weaker effect in equimolar concentrations (Kitazawa et al. 1997). Previous studies have reported that vascular relaxation to oestrogen is observed in endothelium-denuded preparations (Freay et al. 1997, Jiang et al. 1992, Kitazawa et al. 1997) showing that neither endothelial nitric oxide nor any other factor produced by the endothelium mediates relaxation. In addition, relaxation to oestrogen has been observed in the presence of the nitric oxide synthase inhibitors $N^{\mathrm{G}}$-nitro-L-arginine and $N^{\omega}$-nitro-Larginine (Freay et al. 1997, Lydrup \& Nilsson 1996, Ma et al. 1997). Thus, relaxation to $\mu \mathrm{M}$ concentrations of oestrogen is evoked via a direct effect on vascular smooth muscle cell properties.

In vascular preparations precontracted with $\mathrm{KCl}$ or noradrenaline acute relaxation following exposure to $17 \beta$ oestradiol is observed (Kitazawa et al. 1997). The effect of $17 \beta$-oestradiol is potentiated with time of exposure (Freay et al. 1997, Lydrup \& Nilsson 1996). Pretreatment with the protein synthesis inhibitor cycloheximide or the RNA synthesis inhibitor actinomycin D has no effect on $17 \beta$ oestradiol-induced vascular relaxation (Freay et al. 1997, Kitazawa et al. 1997). The rapid onset of relaxation and the lack of effect of protein and RNA synthesis inhibition suggest that vascular relaxation is a non-genomic effect of $17 \beta$ oestradiol.

Two oestrogen receptor (ER) subtypes ( $\alpha$ and $\beta$ ) have been identified. ER $\alpha$ expression, detected by RT-PCR has been found in rat uterus, testis, pituitary, ovary, kidney and adrenals (Kuiper et al. 1997). Kuiper and co-workers (1996) cloned a novel ER subtype $(\beta)$ from rat prostate using Northern blot and RT-PCR. ER $\beta$ expression was found in a number of organs from the rat such as prostate, ovary, testis, bladder, lung, uterus, small intestine and brain (Kuiper et al. 1996, 1997, Saunders et al. 1997). Recently, Saji et al. (2000) have shown high expression of ER $\beta$ in rat mammary gland. Specific and high affinity binding sites for radiolabelled $17 \beta$ oestradiol have been found in mouse and rat aorta (Freay et al. 1997, Lin \& Shain 1985). In rat aortic smooth muscle cells $\mathrm{ER} \alpha$ expression has been visualized using immunocytochemistry (Orimo et al. 1993). In both mouse and rat aorta expression of mRNA for ER $\beta$ has been observed (Iafrati et al. 1997, Lindner et al. 1998).

Vascular relaxation in response to $\mu \mathrm{M}$ concentrations of oestrogen is not different in wild-type mice compared with mice lacking a functional ER $\alpha$ indicating that ER $\beta$ might be responsible (Freay et al. 1997). The aim of the present study was to investigate the importance of ER $\beta$ for relaxation caused by pharmacological concentrations of oestrogen by using arterial preparations from mice lacking functional ER $\beta$. 


\section{Materials and Methods}

Adult female and male mice (6-7 months old) lacking functional $\operatorname{ER} \beta(-/-)$ and their wild-type litter mates $(+/+)$ were used. The $-/-$ mice were generated by targeted disruption of exon three of the ER $\beta$ gene as described previously (Krege $e t$ al. 1998). Lack of ER $\beta$ in -/- mice was confirmed by RT-PCR for ER $\beta$ mRNA and by Western blot of nuclear extracts from lung and brain showing absence of ER $\beta$ mRNA and protein in -/- but not in $+/+$ mice. In aorta of wild-type mice ER $\beta$ mRNA is expressed, while it is not detectable in aorta of ER $\beta$ knockout mice (Karas et al. 1999). Mice were weighed and then sacrificed by cervical dislocation. The experiments were approved by the Animal Ethics Committee at Lund University. The abdominal aorta from the iliac bifurcation to the diaphragm was dissected free from fat and connective tissue and placed in cold $\mathrm{Ca}^{2+}$-free HEPES-buffered solution (for composition see below). The aorta was cut into about 20 uniform rings (0.5-0.8 $\mathrm{mm}$ in width) using a dissecting microscope. Rings were chosen randomly for either force measurements or prepared for morphology.

\section{Force measurements}

Rings were mounted on two stainless steel wires, one of which was connected to a force transducer (AE 801, SensoNor A/S, Horten, Norway) and instantly immersed in exchangeable Plexiglass cups filled with $400 \mu$ l HEPES-buffered solution. The preparations were allowed to equilibrate at a passive tension of about $0.5 \mathrm{mN}$, corresponding to optimal length for active force, at $37^{\circ} \mathrm{C}$ for $60 \mathrm{~min}$ before experiments were started.

\section{Experimental protocol}

In one set of experiments sensitivity to $17 \beta$-oestradiol was investigated by adding the steroid $(1-100 \mu \mathrm{M})$ cumulatively to a preparation precontracted with noradrenaline $(10 \mu \mathrm{M})$. Each concentration of $17 \beta$-oestradiol was present for $15 \mathrm{~min}$ before a higher concentration was added. Force responses at 5, 10 and 15 min were normalized to those of control rings that received vehicle (ethanol) and were run in parallel. No run-down of force was observed in control rings. In another set of experiments concentration-response relationships for noradrenaline $(1 \mathrm{nM}-50 \mu \mathrm{M})$ were determined. At the end of experiments the width of the rings were measured using a microscope equipped with an ocular scale. Force was expressed as relative and absolute $(\mathrm{mN} / \mathrm{mm})$ force.

\section{Solutions}

Dissection was performed in $\mathrm{Ca}^{2+}$-free and force measurements in $\mathrm{Ca}^{2+}$-containing HEPES buffered solution of the following composition (in $\mathrm{mM}$ ): $\mathrm{NaCl} 135.5, \mathrm{KCl} 5.9, \mathrm{CaCl}_{2} 2.5, \mathrm{MgCl}_{2}$ 1.2, N-2-hydroxyethylpiperazine- $\mathrm{N}^{\prime}$-2-ethane-sulphonic acid (HEPES) 11.6 and glucose 11.5.

\section{Drugs}

Noradrenaline was purchased from Apoteksbolaget, Sweden. All other chemicals were from Sigma Chemical (St Louis, MO, USA). $17 \beta$-oestradiol was dissolved in ethanol.

\section{Morphology}

Rings were fixed overnight in a mixture of $2 \%$ formaldehyde and $0.2 \%$ picric acid in phosphate buffer $(\mathrm{pH} 7.2)$ followed by thorough rinsing in Tyrode's solution containing 10\% sucrose. Specimens were then frozen on dry ice and cross sections were cut in a cryostat to a thickness of $10 \mu \mathrm{m}$. Sections were processed for morphometry or immunocytochemistry.

\section{Morphometric analysis}

Automated measurements of the thickness of the media of aorta, were performed using a computerized image analyzing system (Leica, Q500MC). Measurements were performed on hematoxylin-eosin stained cross sections, at 3-4 different depths, from the aorta of $-/-$ and $+/+$ mice ( $n=3$ in each group). The width of the media was defined using a binary cursor. Data was presented as average of 30 measurements.

\section{Immunocytochemistry}

Sections were incubated overnight with a polyclonal antiserum raised in rabbit against factor VIII (von Willebrand factor, dilution 1:640, code No A 082, Dakopatts, Copenhagen, Denmark) in order to determine the presence of endothelium in aorta of -/- and +/+ mice. The site of the antigen-antibody reaction was visualized by fluorescein isothiocyanate (FITC)conjugated antibodies to rabbit Ig G raised in pig (Dakopatts, Copenhagen, Denmark).

\section{Statistics}

Values are presented as means \pm S.E.M. Statistical significance was determined by Student's two-tailed $t$-test for unpaired comparisons. $P$-values less than 0.05 were regarded as statistically significant. For multiple comparisons, the Bonferroni method for determination of statistical significance was used.

\section{Results}

The weights of ER $\beta$ knock-out (-/-) male and female mice were similar to corresponding wild-type $(+/+)$ animals (Fig. 1, panel A). Females had a lower body weight compared with males $(26.1 \pm 0.8$ vs $32.4 \pm 2.0 \mathrm{~g}, n=6, P<0.05)$. Maximal noradrenaline-evoked force was similar in aortic rings from -/and $+/+$ animals (Fig. 1, panel B). No difference in noradrenaline sensitivity was observed between aortic preparations from $-/-$ and $+/+$ males or females. The $\mathrm{EC}_{50}$ values for $-/-$ and $+/+$ animals were $1.32 \pm 0.40 \mu \mathrm{M}(n=11)$ and $1.94 \pm 0.45 \mu \mathrm{M}(n=8)$, respectively.

In Fig. 2 (upper panel) cross sections of hematoxylin-eosin stained aortic preparations from $-/-$ and $+/+$ female mice are 


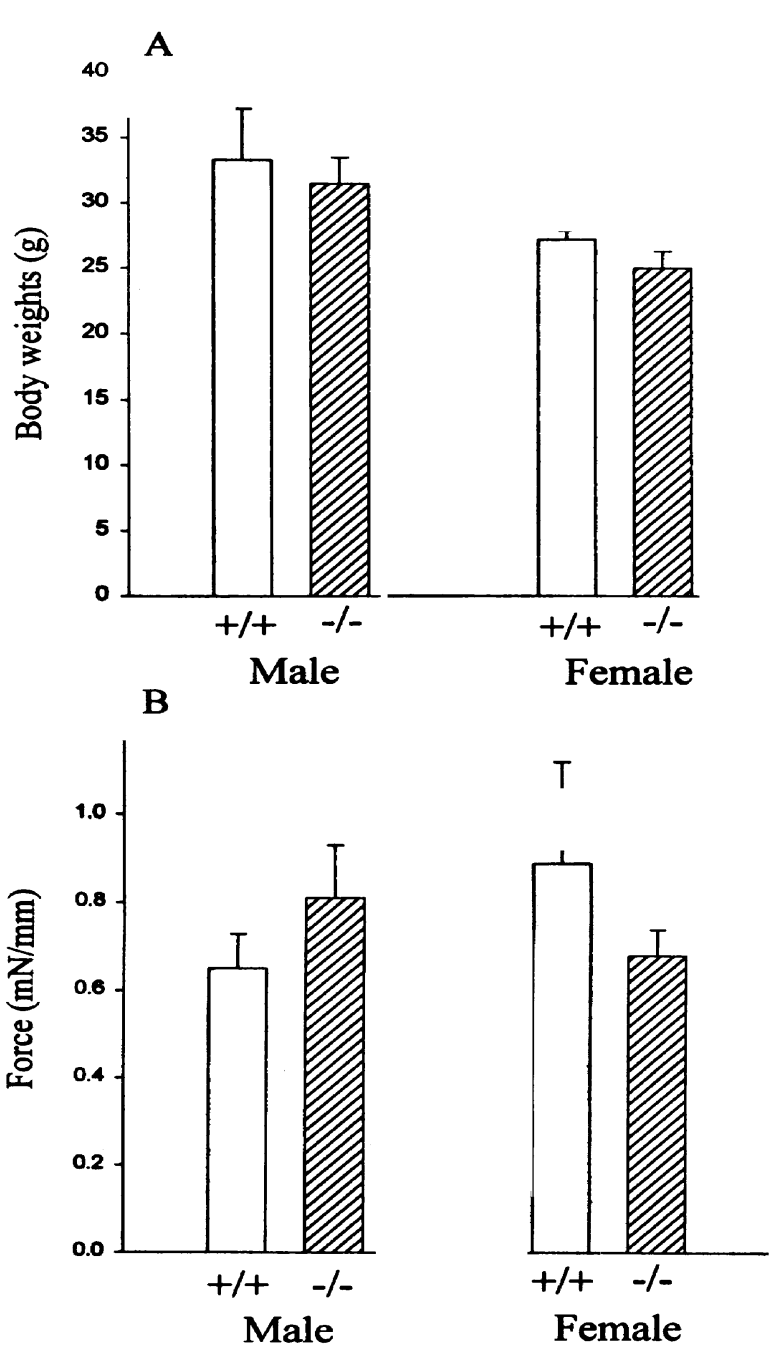

Figure 1 (A) Body weights of wild-type $(+/+)$ and ER $\beta$ knock-out $(-/-)$ male and female mice ( $n=3$ in each group) and (B) maximal noradrenaline-evoked force $(\mathrm{mN} / \mathrm{mm})$ in aortic rings from $+/+$ and -/- mice $(n=15-19)$. Values are means \pm S.E.M.

shown. No visible difference in vascular wall structure was observed between sections from -/- and $+/+$ irrespective of sex. The thickness of the media was determined using a computerized image analyzing system. The average width was $43.1 \pm 1.4 \mu \mathrm{m}(n=30)$ in $-/-$ animals compared with $41.7 \pm 1.2 \mu \mathrm{m}$ $(n=30)$ in $+/+$ animals. In both $-/-$ and $+/+$ animals intact endothelium could be visualized using immunocytochemistry for von Willebrand factor (Fig. 2, lower panel). Morphological data thus show unaltered aortic wall structure in -/- animals.

Cumulative addition of $17 \beta$-oestradiol $(1-100 \mu \mathrm{M})$ to aortic rings of male and female mice precontracted with $10 \mu \mathrm{M}$ noradrenaline caused a concentration-dependent relaxation. Force was evaluated at 5, 10 and 15 min of exposure to each concentration of $17 \beta$-oestradiol and normalized to that of
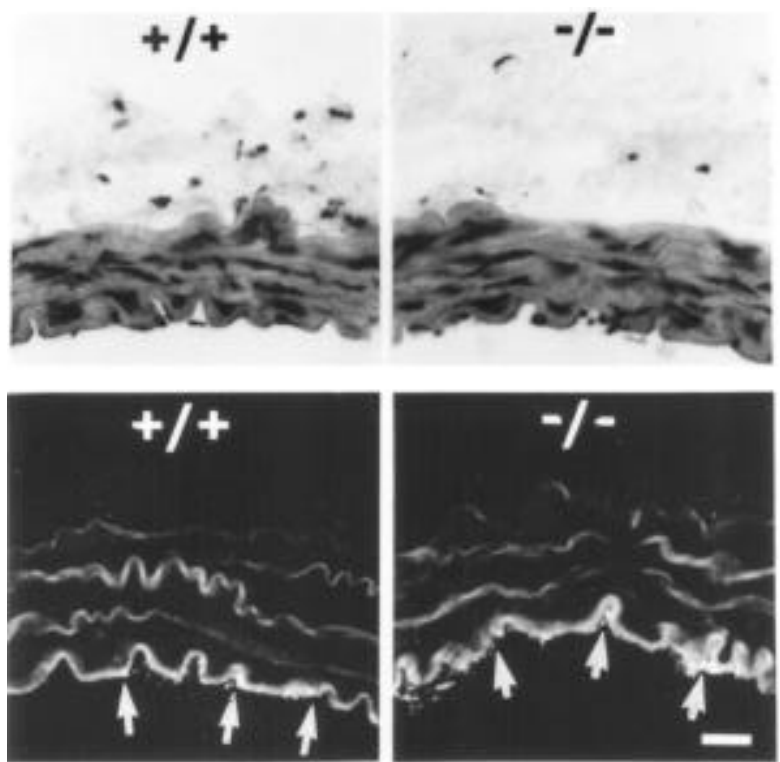

Figure 2 Cross sections of aorta from wild-type $(+/+)$ and ER $\beta$ knock-out (-/-) female mice stained with hematoxylin-eosin (upper panel) or with an antiserum against von Willebrand factor (lower panel). Arrows indicate immunoreactive endothelium; elastic fibers in the media show autofluorescence. Bar $20 \mu \mathrm{m}$.

control rings. Relaxation in response to each concentration of the steroid was potentiated with time. In Fig. 3 summarized data on force-responses obtained at $5 \mathrm{~min}$ after addition of 1$100 \mu \mathrm{M} 17 \beta$-oestradiol to aortic rings from $-/-$ or $+/+$ mice of both sexes are shown. Relaxation to $17 \beta$-oestradiol was more pronounced in preparations from $-/-$ than from $+/+$ mice. This effect was observed in mice of both sexes. Rings from both wild-type and knock-out female mice tended, however not statistically significant, to be more sensitive to $17 \beta$-oestradiol than the corresponding ones from males. Vascular supersensitivity to $17 \beta$-oestradiol in -/- mice was observed also after longer time periods (10 and $15 \mathrm{~min}$ ) of exposure to each concentration of the steroid.

\section{Discussion}

In the present study we observed a more pronounced vascular relaxation by $\mu \mathrm{M}$ concentrations of $17 \beta$-oestradiol in ER $\beta$ deficient than in wild-type mice. This suggests that ER $\beta$ modulates oestrogen-induced vascular relaxation but is not responsible for relaxation per se. In the ER $\beta$ deficient mice stimulation with oestrogen involves activation of ER $\alpha$ only and thus activation of this receptor is unopposed by ER $\beta$. However, based on our findings and those by Freay and coworkers (1997) showing that oestrogen causes relaxation in aorta from mice lacking functional $\mathrm{ER} \alpha$ and that these preparations are equally sensitive to oestrogen as those from wild-type mice, vascular supersensitivity to oestrogen may 


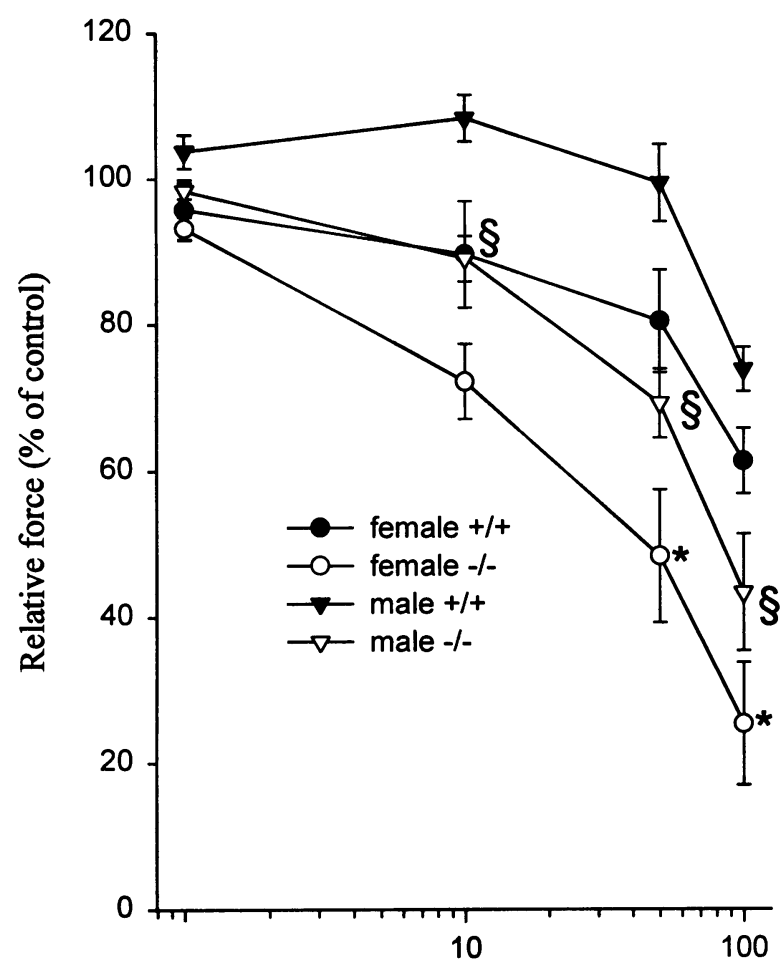

$17 \beta$-oestradiol $(\mu \mathrm{M})$

Figure 3 Effect of $17 \beta$-oestradiol added to aortic rings from $+/+$ and -/- mice precontracted with $10 \mu \mathrm{M}$ noradrenaline. When a stable contraction to noradrenaline was achieved increasing concentrations of $17 \beta$-oestradiol was added in a cumulative manner. Each concentration was present for $15 \mathrm{~min}$.

Concentration-response relationship was evaluated at 5, 10 and $15 \mathrm{~min}$ and normalized to that of control rings run in parallel. In this figure force responses at $5 \mathrm{~min}$ of exposure are shown. Values are means \pm S.E.M. $n=4-6$. ${ }^{*} P<0.05$ when compared with female $+/+$ and $\S P<0.05$ when compared with male $+/+$.

perhaps not be mediated through ER $\alpha$ but through another ER or another nonreceptor dependent mechanism. Another possibility is that ER $\alpha$ and ER $\beta$ may have partially redundant functions and may substitute for one another when one of them is deleted.

Previously reported studies on vascular smooth muscle cells have shown that $17 \beta$-oestradiol, in the same concentration-range as used in this study, interacts with plasma membrane ion-channel properties, e.g. inhibits $\mathrm{Ca}^{2+}$ channels and activates $\mathrm{BK}_{\mathrm{Ca}}$ channels (Zhang et al. 1994, White et al. 1995), suggesting that vascular smooth muscle cells contain plasma-membrane ER. Absence of ER $\beta$ as in ER $\beta$ knock-out animals might cause upregulation and/or enhanced activity of another, yet unknown, ER that may modify membrane properties. Upregulation of such a receptor will thus lead to a more pronounced relaxation in response to oestrogen. It is also possible that, normally, ER $\beta$ dampens vasorelaxation induced by $E R \alpha$ so that this effect becomes more pronounced after deletion of ER $\beta$. Such an antagonistic effect of ER $\beta$ on ER $\alpha$ has been seen in other contexts (J-A Gustafsson, unpublished observations). A double knock-out animal that lacks both ER $\alpha$ and ER $\beta$ will provide a definite answer as to which of the two explanatory models is most relevant.

Vascular wall structure was similar in sections of aorta from ER $\beta$ knock-out and wild-type mice. Animals lacking ER $\beta$ had unchanged medial wall thickness and capacity to produce force in response to noradrenaline and these quantitative measurements support that vascular wall structure is intact in ER $\beta$ knock-out animals. ER $\beta$ is thus probably not important for vascular development but is suggested to set sensitivity of vascular smooth muscle to high concentrations of oestrogen.

\section{Acknowledgements}

This study was supported by grants from the Swedish Medical Research Council (04X-13017-01A and 04X-13406-01A), The Swedish Heart and Lung Foundation and the foundations of Åke Wiberg and Magnus Bergwall as well as from the Swedish Cancer Fund and Karo BioAB.

\section{References}

Freay AD, Curtis SW, Korach KS \& Rubanyi GM 1997 Mechanism of vascular smooth muscle relaxation by estrogen in depolarized rat and mouse aorta. Circulation Research 81 242-248.

Iafrati MD, Karas RH, Aronovitz M, Kim S, Sullivan TR Jr, Lubhan DB, O’Donnell TF Jr, Korach KS \& Mendelsohn ME 1997 Estrogen inhibits the vascular injury response in estrogen receptor $\alpha$-deficient mice. Nature Medicine 3 545-548.

Jiang C, Sarrel PM, Poole-Wilson PA \& Collins P 1992 Acute effect of $17 \beta$-estradiol on rabbit coronary artery contractile response to endothelin-1. American Journal of Physiology 263 H271-H275.

Karas RH, Hodgin JB, Kwoun M, Krege JH, Aronovitz M, Mackey W, Gustafsson J-Å, Korach KS, Smithies O \& Mendelsohn ME 1999 Estrogen inhibits the vascular injury response in estrogen receptor $\beta$-deficient female mice. PNAS 96 15133-15136.

Kitazawa T, Hamada E, Kitazawa K \& Gaznabi KM 1997 Nongenomic mechanism of $17 \beta$-oestradiol-induced inhibition of contraction in mammalian vascular smooth muscle. Journal of Physiology 499 497-511.

Krege JH, Hodgin JB, Couse JF, Enmark E, Warner M, Mahler JF, Madhabananda S, Korach KS, Gustafsson J-Å \& Smithies O 1998 Generation and reproductive phenotypes of mice lacking estrogen receptor $\beta$. PNAS 95 15677-15682.

Kuiper GGJM, Carlsson B, Grandien K, Enmark E, Häggblad J, Nilsson S \& Gustafsson J-A 1997 Comparison of the ligand binding specificity and transcript tissue distribution of estrogen receptors $\alpha$ and $\beta$. Endocrinology 138 863-870.

Kuiper GGJM, Enmark E, Pelto-Huikko M, Nilsson S \& Gustafsson J$\AA 1996$ Cloning of a novel estrogen receptor expressed in rat prostate and ovary. PNAS $\mathbf{9 3} 5925-5930$. 
Lin AL \& Shain SA 1985 Estrogen-mediated cytoplasmic and nuclear distribution of rat cardiovascular estrogen receptors. Arteriosclerosis 5 668-677.

Lindner V, Kim SK, Karas RH, Kuiper GGJM, Gustafsson J-Å \& Mendelsohn ME 1998 Increased expression of estrogen receptor- $\beta$ mRNA in male blood vessels after vascular injury. Circulation Research 83 224-229.

Lydrup M-L \& Nilsson B-O 1996 Acute and long-term effects of $17 \beta$ oestradiol on agonist- stimulated force in rat tail artery. Acta Physiologica Scandinavica 158 253-259.

Ma L, Robinson CP, Thadani U \& Patterson E 1997 Effect of 17- $\beta$ estradiol in the rabbit: endothelium-dependent and -independent mechanisms of vascular relaxation. Journal of Cardiovascular Pharmacology 30 130-135.

Orimo A, Inoue S, Ikegami A, Hosoi T, Akishita M, Ouchi Y, Muramatsu M \& Orimo H 1993 Vascular smooth muscle cells as target for estrogen. Biochemical and Biophysical Research Communication 195 730-736.

Saji S, Jensen EV, Nilsson S, Rylander T, Warner M \& Gustafsson J-Å 2000 Estrogen receptors $\alpha$ and $\beta$ in the rodent mammary gland. PNAS 97 337-342.

Saunders PTK, Maguire SM, Gaughan J \& Millar MR 1997 Expression of oestrogen receptor beta $(\mathrm{ER} \beta)$ in multiple rat tissues visualised by immunohistochemistry. Journal of Endocrinology 154 R13R16.

White RE, Darkow DJ \& Falvo-Lang JL 1995 Estrogen relaxes coronary arteries by opening $\mathrm{BK}_{\mathrm{Ca}}$ channels through a cGMPdependent mechanism. Circulation Research 77 936-942.

Zhang F, Ram JL, Standley PR \& Sowers JR 1994 17ß-oestradiol attenuates voltage-dependent $\mathrm{Ca}^{2+}$ currents in A7r5 vascular smooth muscle cell line. American Journal of Physiology 266 C975-C980. 